\section{DIRECTIONS FOR CHILD HEALTH IN THE 21ST CENTURY}

\section{GUEST EDITORIAL}

Victor Nossar

Service Director, Department of Community Paediatrics

South Western Sydney Area Health Service

\section{Garth Alperstein}

Community Paediatrician, Community Health Services

Central Sydney Area Health Service

Due to the high level of interest shown in the four-part series on improving the health of children in NSW, published in the May, June-July, October and November 1998 issues of the NSW Public Health Bulletin, this fifth issue in the series has been produced to review the progress achieved in child health since then.

Professor Nick Spencer, Professor of Child Health at the University of Warwick, was invited to review the content of the series, and in a feature article provides an international perspective on the initiatives described, while reflecting on some of the key issues that the series raised. The article by Wraith and Murphy provides an overview of the history and development of child health policy in NSW, while the article by Quaine, Jorm and Williamson introduces readers to the development of a statewide child health survey. The article by Hudson on Families First describes how some of the matters raised in the original series are being translated into services for children in NSW. Finally, Bowen and Gray, in their report on health promotion in schools, demonstrate the value of a structured approach to intersectoral work, and the important contribution of schools to children's health and life outcomes.

Together these papers add useful detail to the concepts and ideas introduced in the first four parts of the series, and demonstrate progress in the efforts to improve the health of children in NSW into the 21 st century. 5

\section{CONTENTS}

69 Guest editorial: Directions for child health in the 21st century

$70 \quad$ Improving the health of children in NSW: a view from the United Kingdom

72 Child health policy in NSW: building on a century of care

75 Development of the NSW Child Health Survey

77 Progress on Families First : a support network for families raising children

$80 \quad$ Health promotion with schools: a policy for the NSW health system

81 Our people, our health, our future: Murdi Paaki Regional Council Health Summit

83 FactSheet : Parvovirus B19 and 'fifth disease' 